
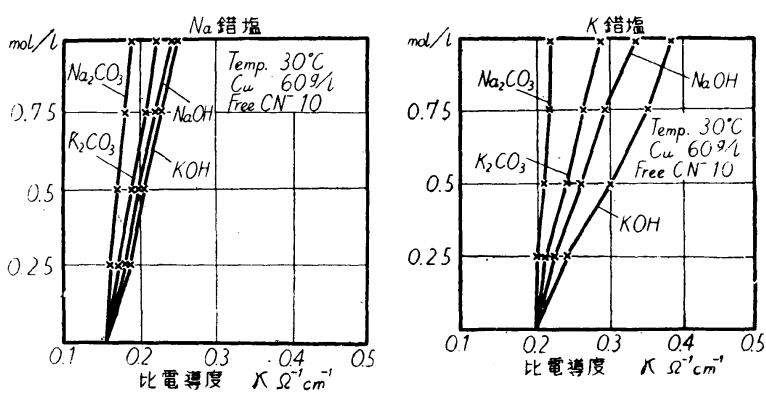

第 12 図

く減少する。また光沢剤の添加は低電流密度に扮いては 分極が增加するが電流密度の增加につれて減少し, 光沢 は減少した点から水素ガス発生までの電流密度で生ず る。また同一銅䀼度ではカリウム錯塩の方がナトリウム 錯塩より分極が少ない。これらの点を総合すると，分極 を減少させる因子がすべて光沢化化寄与することが第 1 報を参照すると判る。

つぎにカリウム塩の効果を確める別の方法として電導 度を測定したが, 確にカリウム塩の添加によって電導度 が增加することは判ったが，乙れが光沢改善の主なる原 因とは考えられない。
またカリウム錯塩とナトリウム錯塩の電導度を 比較してもこの雨者の解離恒数がいちじるしく違 らとも考觉られない。しかると種々の点でカリウ 么錯塩の效果が認められるのは，カリウム塩の存 在により陰イオンが放電した後の解離速度がは やめられ，電苗されるイオンの補給が速かになる ためでないかと考えられる。きわめて大胆な結論 であるが，さらにこれを証明するためには二三の 研究が必要であるが一応本報告の結諭として招 <。

(1957.6.4 受理)

昭和 31 年 6 月表面技術協会 䂺究発表の8の)

文献

1) Spitzer : Z. Electrochem., 11 (1904) 345

2) Foerster : Z. Electrochem., 13 (1907) 561

3) Getman : Trans. Am. Electrochem, Soc., 26 (1914) 67

4) Haring \& Blum: Trans. Am. Electrochem. Soc., 44 (1923) 313

5) Smith \& Brekenridge : Trans. Am. Electrochem. Soc., 56 (1929) 397

6) Glasstone : J. Am. Chem. Soc., 131 (1929) 702

7) Pan: Trans. Am. Electrochem. Soc., 68 (19 35) 477

\title{
リン酸処理せる各種アルミニウム合金表面の オートラジオグラフィ
}

\author{
麻田宏*。堀口泰裕 * 富田耕平*
}

\section{Autoradiography of $\mathbf{P}^{32}$ Deposited on Surface of Aluminium}

\author{
Alloys Treated with Phosphoric Acid Solution.
}

\section{Hiroshi ASADA*, Yasuhiro HORIGUCHI* and Kohei TOMITA*}

The conclusion of the previous report concerning the phosphoric acid treatment was as follows:

There remains no phosphoric compound on the surface of aluminium alloy plates, if it is rinsed immediately after the phosphoric acid treatment. However, when the plates are dryed after phosphoric acid treatment, the phosphoric compound adheres strongly on the surface notwithstanding the violent rinsing operation. In this report, the positions of phosphorus deposited on the surface of aluminium alloys are revealed by the autoradiograph of $\mathrm{P}^{32}$. As a result of the experiment, the positions of $\mathrm{P}^{32}$ distribute on the surface according to the structure of the aluminium alloys.

It is not clear that whether the phosphorus deposited on the surface of aluminium alloys is a different compound or the phosphoric acid solution itself remained in small cavities. In any case the phosphorus $\left(\mathrm{P}^{22}\right)$ is in the insoluble state, because the testpieces of the autoradigraph are rinsed very thoroughly.

As to $\mathrm{Al}-\mathrm{Mg}$ alloy, the film of phosphoric compound seemes to grow over thesurface of the alloy. As to Al-Si alloy and $\mathrm{Al}-\mathrm{Si}-\mathrm{Cu}$ alloy, the phosphoric compound seems to deposit in the cavities of eutectic structure. As to $\mathrm{Al}-\mathrm{Fe}$ series alloys, the phosphoric compound seems to deposit rather on the crystal of $\mathrm{FeAl}_{3}$ than in the cavity of crystal boundary of $\mathrm{FeAl}_{3}$. In brief, the deposition of phophoric compound by the phosphoric acid treatment does not cover all over the surface aluminium alloy but partially over it according to the microscopic structure of aluminium alloy.

* 東京大学理工学研究所(東京都目黑区駒場町) Institute of Science and Tchnology, University of Tokyo. 


\section{1. 緒 言}

現在アルミニウム合金を塗装する場合，その前処理と してリン酸液による処理を行う場合がしばしばある。

著者等は既報のように， $\mathrm{P}^{32}$ を利用した実験に扣い て次のことを明らかにした。すなおち，アルミニウムお よびアルミニウム合金をリン酸溶液に浸セキしただけで は，表面にいさ」かもリンの残存するのを認め得なか一 た。しかし溶液を表面に叙布し乾燥させると, その後, 表面を十分脱脂綿で水洗した後もな打リンの存在を認め た。この場合リンの存在は単なる付着によるるのか，ま るいは化合物の生成によるものかは判明しないが、なん らかの形のリンの存在を示すととは明らかである。

本実験に招いては， $\mathrm{P}^{32}$ の放射能を利用してオートラ シオグラフを撮り，アルミニウム合金の表面存在する リンの位置を調べるのを目的とした。

\section{2. 実 験 材 料}

2-1. 使用した合金の種類
1. $\mathrm{A} 1-7 \% \mathrm{Si}$ 合金
4. Al-Fe 合金

2. $\mathrm{Al}-2 \% \mathrm{Cu}-2 \% \mathrm{Si}$ 合金

5. $\mathrm{A} 1-4 \% \mathrm{Cu}-1 \% \mathrm{Fe}$ 合金

3. $\mathrm{Al}-7 \% \mathrm{Mg}$ 合金

6. $\mathrm{Al}-4 \% \mathrm{Mg}-1 \% \mathrm{Fe}$ 合金

以上6種の鋳物を使用した。なお，アルミニウム地金 は第1表法すような成分のものである。

2-2. 処理に用いたリン酸溶液は, $100 \mathrm{cc}$ 中 $3 \mathrm{mc}$ の $\mathrm{P}^{32}$ を含さリン酸を，エチルアルコールと 1:3 の割合に混 和したものである。これに用いた $\mathrm{P}^{32}$ は第 2 表に示すよ ろなものである。すなわち orthophcsphate を希塩酸で 溶かし $\mathrm{pH} 2 \sim 3$ とし， これに多量のリン酸を加壳たも のなのでリン酸への分解は十分と思われる。

使用した感光䬉は富士フィルム製の富士オートラジオ

第1表 使用したアルミニウムの分析値

\begin{tabular}{l|c|c|c|c|c|c}
\hline $\mathbf{M}$ & $\mathrm{Al}$ & $\mathrm{Cu}$ & $\mathrm{Si}$ & $\mathrm{Fe}$ & $\mathrm{Mn}$ & $\mathrm{Zn}$ \\
$\%$ & 99.26 & 0.03 & 30 & 0.41 & 0.01 & $\mathrm{tr} \cdots$ \\
\hline
\end{tabular}

第2表 使用した $\mathrm{P}^{32}$

\begin{tabular}{c|c}
\hline radioisotope & phosphorous -32 \\
\hline preparation & orthophsphate in dilute $\mathrm{HCl}$ \\
chemical purity & $99 \%$ \\
\hline $\mathrm{pH}$ & $2 \sim 3$ \\
\hline
\end{tabular}

...from Radiochemical Center; England...
グラフ用乾板 (ストリップ用) Type ET-2E でこの乳剂

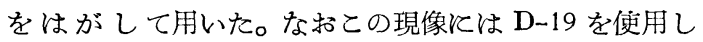
た。金属と感光刜が直接ふれる時は, 全面黑化を生ずる おそれがあるので，この間に中間風としてごくうすい絶 縁性の膜を使用せね齐ならないが，本実験に招いてはセ ロイシン $0.5 \%$ 酢酸アミルに溶かした液を使用した。

\section{3. 実 験 方 法}

各合金をペーパー执よびバフで仕上げた後，紬織を検 鏡して打き，ついで武料に $\mathrm{P}^{32}$ を含む处理液を鉒布し， 乾燥後, 十分脱脂綿でこすりながら水洗し，反応したと 思われる以外のリン酸は洗い落してしまう。カウンター によって表面に残存する $\mathrm{P}^{32}$,を確認して捈く。その後, 表面に 0.5 セロイシン一酢酸アミル溶液を叙布して乾 燥し中間䛻を作る。この中間風はあまり厚いとフィルム の解像力をそとなうのでできるだけうすく均一にする。 これは電子顐微鏡のレプリカと同程度のものである。

以上の好理を行った試料にエマルショョをのせるので あるが，この方法は蒸留水中で乾板よりエマルションの 膜を引きはがし適当な大きさに切り試料にのせ，水中よ り引上げる。しかる後, 適当な乾燥を行い表面に一樣な 膜が張れたならばデシケータ中で適当時間放置露出す る。本実験に沶いては10〜14日閒放置した。この間, $\beta$-線 によりエマルジョンは感光する。露出後, ふたたび蒸 留水中で試料からエマルジョンを引きはがし, D-19 に より現像し，以下他のフィルムと同樣に定着水沙を行う。 その後エマルションをふたたびスライドグラス上に載

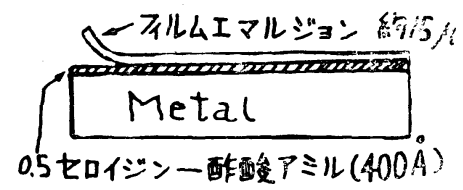

第1図露出方法

せ，乾燥し，顕微鏡によりその黒化分布を調べる。第 1 図は金属上のエマルジョンの露出方法を示す。

\section{4. 実 験 結 果}

アルミニウム合金表面の組織写真招よびそのオートラ ジオグラフを以下に示す。

4-1. A1-7\% Si 合金写真1, 写真2に示すよ5に $\mathrm{P}^{32}$ は主として合金の共晶部分飞存在し, 初晶にはほ んど表われない, 更によくみると共昆の黒化部分は細か く入り交っているのが判る。 


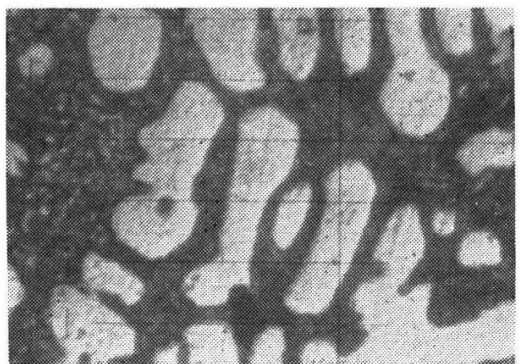

写真 1 Al-Si 合金組織写真 $\times 240$

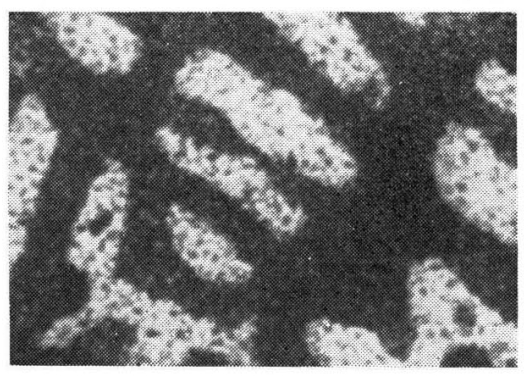

写真 $2 \mathrm{Al}-\mathrm{Si}$ 合金 Autoradiograph $\times 240$

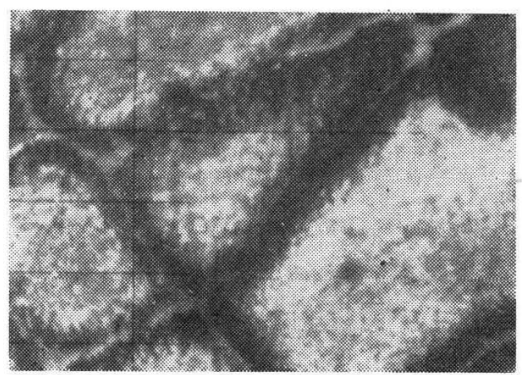

写真 3 Al-Si-Cu 合金組織写真 $\times 240$

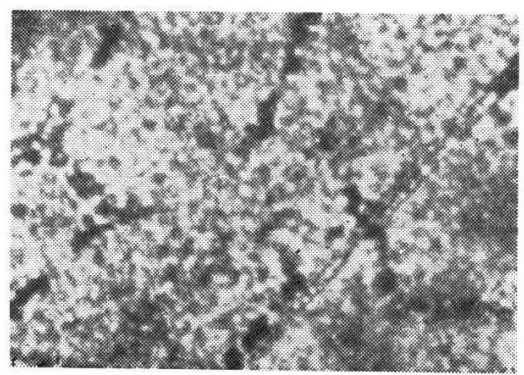

写真 4 Al-Si-Cu 合金 Autoradiograph $\times 240$

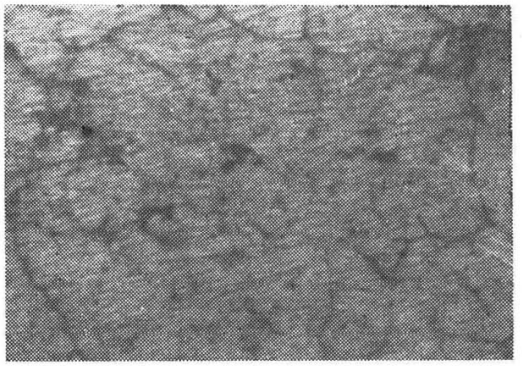

写真 5 Al-Mg 合金組織与真 $\times 240$

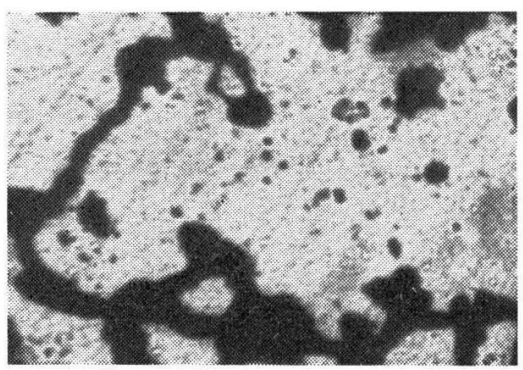

写真 6 Al-Mg 合金, Autoradiograph $\times 240$

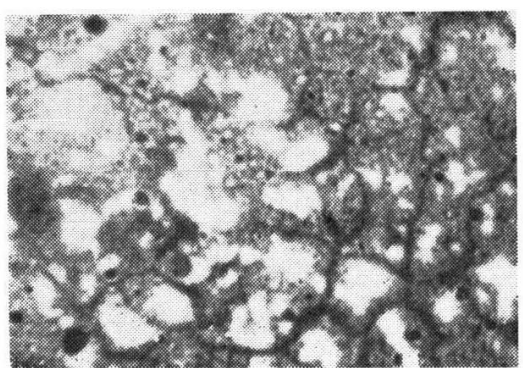

写真 7 Al-Mg 合金, Autoradiograph $\times 240$

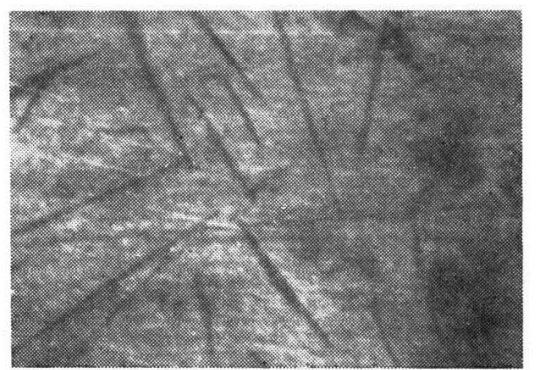

写真 $8 \mathrm{Al}-\mathrm{Fe}$ 合金組織写真 $\quad \times 80$
4-2. $\mathrm{A} 1-2 \% \mathrm{Cu}-2 \% \mathrm{Si}$ 合金 写真 3, 写真 4よりみ ると, この合金に打いては, 全面的に $\mathrm{P}^{32}$ が存在する。 また, 特に強い黑化点が連続して粒界を表わすようにみ えるが，もしとれが粒界であるとすれば，黑化点は粒界
に表われた共晶部分に相当するものと考皇られる。 4-3. $\mathrm{Al}-7 \% \mathrm{Mg}$ 合金写真 5 , 写真 6 , 写真 7 を観 察すると，この恶の合金対しては，その金属組織とリ ンの付着状況との圏係は不朋確である。しかし, 粒界か 


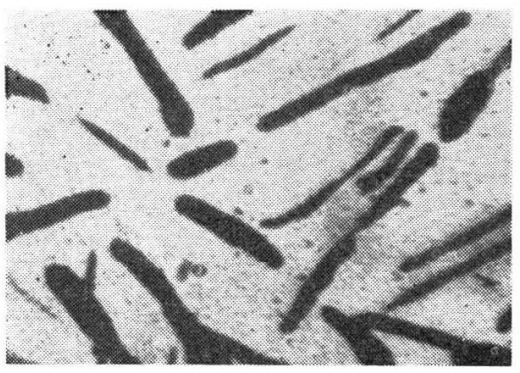

写真 $9 \mathrm{Al}-\mathrm{Fe}$ 合金 Autoradiograph $\times 80$

ら枝葉が出たようとリンの付着が認められ，何か化合物 の薄腽ができているようにみられる。この合金に対して は，少なくとも前二者の場合と大分異なるるのと考えら れる。

4-4. Al- $\mathrm{Fe}$ 合金 写真 8 , 写真 9 上り, この合金

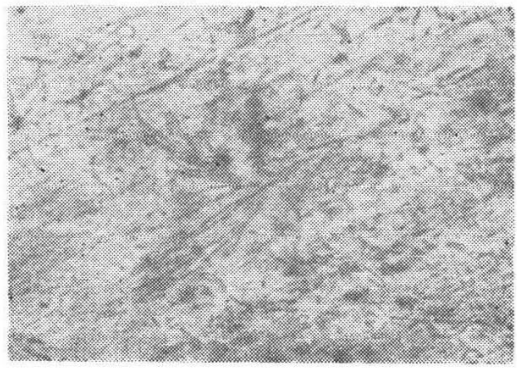

写真10 $\mathrm{Al}-\mathrm{Cu}-\mathrm{Fe}$ 合金組織写真 $\quad \times 120$

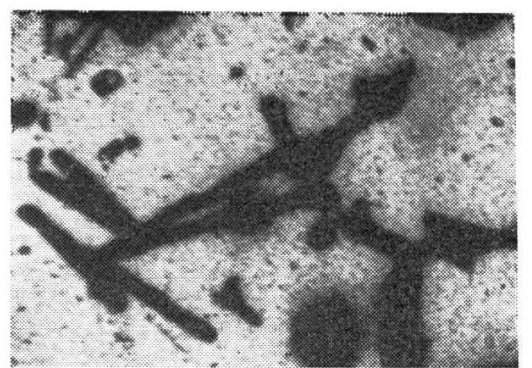

写真11 $\mathrm{Al}-\mathrm{Cu}-\mathrm{Fe}$ 合金 Autoradiograph $\times 120$

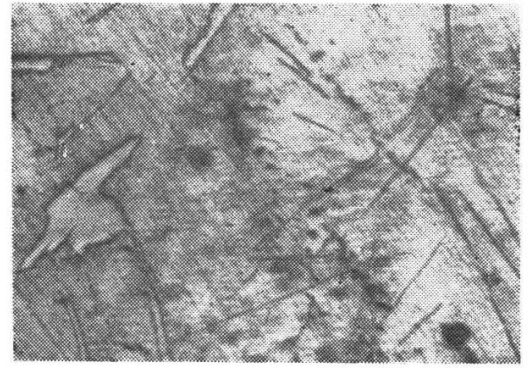

写真12 $\mathrm{Al}-\mathrm{Mg}-\mathrm{Fe}$ 合金組織写真
そ対して $\mathrm{P}^{32}$ は $\mathrm{FeAl}_{3}$ の針状結晶に相当する部分に強く 付着する。素地の部分に $\mathrm{P}^{32}$ の付着はない。

4-5. $\mathrm{Al}-4 \% \mathrm{Cu}-1 \% \mathrm{Fe}$ 合金, 打よび $\mathrm{A} 1-4 \% \mathrm{Mg}-1 \%$ $\mathrm{Fe}$ 合金写真10, 写真11は $\mathrm{Al}-4 \% \mathrm{Cu}-1 \% \mathrm{Fe}$ 合金。 写真12,写真13/ $\mathrm{Al}-4 \% \mathrm{Mg}-1 \% \mathrm{Fe}$ 合金を示すが， 雨者共, $\mathrm{Al}-\mathrm{Fe}$ 笔合金と同梯飞針状部分飞リンの付着 しているのが期膫に認められる。この部分の他に円く， コアギュ.レートした状照の黑化部分が認められるが，こ の部分はピンホールか，あるいは粒状の化合物を中心と してリンが付着したか，いずれかであるう。

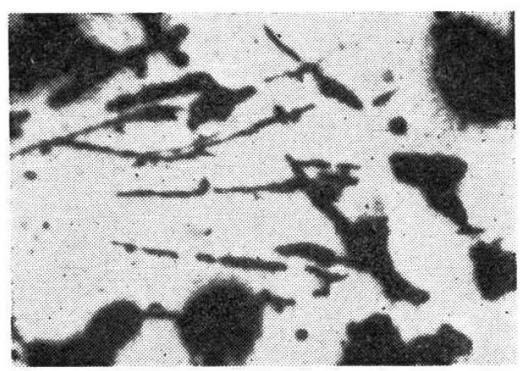

写真13 Al-Mg-Fe 合金 Autoradiograph $\quad \times 120$

\section{5. 総括}

アルミニウム合金の表面にリンが付着する場合，付着 状況は，合金の組織により支配され，各種の分布をかた ちどる。

リンが化合物を作りアルミニウム合金の表面佂定着す るか，あるいは単と部に入り残存するのかは不明であ る。

しかしいずれの場合にしろ，水溶性の状態でないとと は明らかである。上記の写真の結果, Al-Si 合金, Al$\mathrm{Cu}-\mathrm{Si}$ 合金の場合は共晶部に 沈着した 状懸が想像でき る。をた $\mathrm{Al}-\mathrm{Fe}$ 系合金の場合は $\mathrm{FeAl}_{3}$ と素地との境 界が電食により叫部ができて，そとに沈着したと云うよ りは, $\mathrm{FeAl}_{3}$ そのものの上付着したと考えた方が良い ようである。さらに Al-Mg 系においては表面にうすい 化合物の皮膜が被覆する状態が考えられる。

いずれにしろ，合金上へのリン付着は，合金表面全体 を均一飞覆うことなく，それぞれの合金の組織の变化に 上り付着状況す变化するすのと考えられる。

(1957. 7.12 受理)

交献

1）森田，堀口，金属表面技術 5 (1953) 